\title{
Pemberdayaan diri ibu hamil dengan Prenatal Gentle Yoga mempersiapkan persalinan yang lancar, nyaman dan minim trauma
}

\author{
Siskana Dewi Rosita ${ }^{1 *}$, Putriyana ${ }^{2}$ \\ 1,2STIKes Mitra Husada Karanganyar
}

\begin{tabular}{l}
\hline INFORMASI ARTIKEL: \\
\hline Riwayat Artikel: \\
Tanggal diterima: 25 Juni 2021 \\
Tanggal di revisi : 20 Juni 2021 \\
Tanggal di Publikasi : 30 Juni 2021 \\
\hline Kata kunci: \\
Prenatal Gentle Yoga \\
Persalinan
\end{tabular}

Keyword:

Prenatal Gentle Yoga

childbirth

\begin{abstract}
ABSTRAK
Latar belakang: Saat ini masyarakat Indonesia sedang berperang menghadapi wabah COVID-19. Ibu hamil disini masuk dalam kategori yang rentan terpapar, beberapa kelas ibu hamil ditunda, namun tidak bisa diartikan bahwa ibu hamil hanya berdiam diri dirumah. Prenatal yoga gentle memang telah dikenal memiliki dampak positif bagi ibu hamil dan janinnya secara fisik dan mental. Mitra PKM adalah ibu hamil di Desa Madegondo, Kecamatan Grogol, Kabupaten Sukoharjo. Permasalahan mitra adalah kelas ibu hamil selama pandemic covid-19 ditunda cukup lama. Tujuan PKM adalah memberikan kelas ibu hamil secara online sebagai solusi masalah mitra. Solusi yang ingin dicapai adalah ibu hamil tetap bisa aktif melakukan pemberdayaan diri, agar dapat menjalani kehamilan dengan sehat dan pempersiapan persalinan yang lancar, nyaman dan minim trauma.Metode pelaksanaan adalah dimulai dengan survey menganalisi situasi, koordinasi bidan desa untuk melakukan kelas ibu hamil dengan online, serta melakukan evaluasi. Luaran yang akan dihasilkan adalah 1) Mengenal prenatal gentle yoga 2) mempraktiknya prenatal gentle yoga menjelang persalinan, sehingga ibu hamil tetap sehat dan bugar di era new normal.
\end{abstract}

Background: Currently, the Indonesian people are fighting for the COVID-19 outbreak. Pregnant women are included in the category of vulnerable to exposure. Some antenatal classes are postponed, but it does not mean that pregnant women just stay at home. Gentle prenatal yoga has been known to have a positive impact on pregnant women and their fetuses physically and mentally. PKM partners are pregnant women in Madegondo Village, Grogol District, Sukoharjo Regency. The partner problem is that the antenatal classes during the covid-19 pandemic have been postponed for quite a while. The purpose of PKM is to provide online antenatal classes for pregnant women as the solution. The solution aims for pregnant women can still actively carry out self-empowerment in order to have a healthy pregnancy and prepare for a smooth, comfortable and minimally traumatized delivery. The implementation method is starting by a survey to analyze the situation, coordinating local midwives to conduct online classes for pregnant women, and conducting evaluations. The results are 1) getting to know prenatal gentle yoga, and 2) practicing prenatal gentle yoga before delivery so that pregnant women stay healthy and fit in the new normal era.

\section{Pendahuluan}

Persalinan normal adalah suatu proses yang dimulai dengan adanya kontraksi uterus yang menyebabkan terjadinya dilatasi progresif dari serviks, kelahiran bayi dan kelahiran plasenta dan proses tersebut merupakan proses alamiah (Rohani, 2011). Gentle birth adalah sebuah filosofi dalam persalinan yang tenang, penuh kelembuatan dan memanfaatkan semua unsure alami dalam tubuh seorang manusia. Setiap kelahiran adalah pengalaman unik bagi wanita yang melahirkan dan bayi yang dilahirkan. Bagi banyak wanita, pengkondisian sosial awal akan menciptakan keyakinan bahwa mereka tidak dapat melahirkan secara normal.

Adapun perubahan psikologi selama kehamilan trimester III yaitu ibu mulai cemas dan khawatir

\footnotetext{
* Korespondensi penulis.

Alamat E-mail: anonim@mail.com
} 
akan persalinannya kelak. Pada periode ini ibu membutuhkan ketenangan dan dukungan dari suami, keluarga dan tenaga kesehatan. Berat bada ibu meningkat, adanya tekanan pada organ dalam, adanya perasaan cemas dan adanya perubahan gambaran diri (konsep diri, tidak mantap, merasa terasing, takut, dan senang akan kelahiran sang bayi kelak). Dalam proses persalinan organ tubuh memiliki peran penting antara lain panggul dan ligament, tulang belakang serta kaki.

Prenatal Gentle Yoga bukan hanya sekedar mengikuti trend yang diharus dilakukan ibu hamil, namun Prenatal Gentle Yoga sendiri memiliki banyak manfaat, mulai dari menjaga kesehatan ibu hamil, mengurangi kecemasan, mengurangi sakit pinggang, membantu pernafasan lebih baik, melatih pinggul untuk persiapan melahirkan. (Aprilia, 2014)

Sebuah olah raga yang diformulasikan khusus untuk ibu hamil, sebagai sarana olah nafas, tubuh dan pikira untuk memaksimalkan potensi seorang wanita melahirkan alami dengan nyaman, lacar dan minim trauma (Gentle Birth). Maka dari itu penting ibu hamil mengenal prenatal gentle yoga serta dapat mempraktikkan prenatal gentle yoga menjelang persalinan, mengikuti kelas prenatal gentle yoga adalah salah satu cara terbaik bagi ibu hamil, agar dapat menikmati masa kehamilan dengan nyaman, mempersiapkan tubuh dan pikiran untuk proses persalinan yang lancar dan nyaman. Dengan dipandu fasilitator yang berkualifikasi dan berada dilingkungan yang mendukung serta saling mensuport antara ibu hamil satu dengan yang lain.

Melihat pentingnya ibu hamil melalui masa kehamilan dengan nyaman, dapat mengurangi keluhan dengan mandiri, serta mempersiapkan dalam proses persalinan yang normal, sehat, bugar dan minim trauma. Oleh karena itu dalam melaksanakan kegiatan Tri Dharma Perguruan Tinggi pengabdian masyarakat kami tertarik untuk mengadakan pengabdian masyarakat dengan judul "Pemberdayaan Diri Ibu Hamil Dengan Prenatal Gentle Yoga Mempersiapkan Persalinan Yang Lancar, Nyaman dan Minim Trauma" di Desa Madegondo, Kecamatan Grogol, Kabupaten Sukoharjo.

\section{Metode}

Kegiatan pengabdian masyarakat ini dilaksanakan pada kelas ibu hamil. Adapun kegiatan pelaksanaan pengabdian masyarakat adalah sebagai berikut :

1. Penetapan peserta

Dengan meningkatkan pemberdayaan diri ibu hamil dengan Prenatal Gentle Yoga mempersiapkan persalinan yang lancar, nyaman dan minim trauma. Dalam kegiatan ini ibu hamil akan dikenalkan dengan prenatal gentle yoga dan teknik yoga ibu hamil dan dilanjutkan praktik prenatal gentle yoga menjelang persalinan. Sehingga dirumah ibu hamil dapat mempraktikkan dengan mandiri, dan dilakukan setiap hari.

Ibu hamil masuk dalam kategori yang rentan terhadap infeksi virus corona. Pada situasi pandemic COVID-19 diharapkan ibu hamil tidak hanya berdiam diri dan tidak melakukan pemberdayaan diri untuk dapat mendapatkan hak nya untuk melalui proses kehamilan yang sehat dan mempersiapan persalinan dengan baik baiknya. Dalam pengabdian masyarakat ini kami berinovasi, yang biasanya kelas ibu hamil dilakukan secara langsung, karna COVID -19 beberapa bulan ini kelas ibu hamil tidak dilakukan karena tidak diperkenankan untuk berkumpulkan bersama, maka dari itu kami mengadakan kelas online. Sehingga penetapan peserta pengabdian masyarakat ini adalah semua ibu hamil yang mengikuti kelas ibu hamil Desa Madegondo, Kecamatan Grogol, Kabupaten Sukoharjo.

2. Perijinan

Sebelum pelaksanaan pengabdian masyarakat, maka tim pengabdian masyarakat berkoordinasi dengan bidan Desa Madegondo, pemerintah Desa Madegondo, dan para kader kesehatan.

3. Persiapan

Setelah koordinasi dengan Bidan Desa Madegondo ibu Bidan Hesti Ramayani, Amd. Keb dan kader kesehatan melihat kebutuhan informasi ibu hamil dan dan tuntutan ibu hamil agar tetap sehat dan aktif dalam pemberdayaan diri. Maka akan dilaksanakan pengabdian masyarakat dengan judul "Pemberdayaan Diri lbu Hamil Dengan Prenatal Gentle Yoga Mempersiapkan Persalinan Yang Lancar, Nyaman dan Minim Trauma". Kemudian tim segera menyiapkan proposal dan materi serta video yoga ibu hamil yang dapat dipraktikkan di rumah. Menyiapak Media yang digunakan adalah aplikasi Zoom Cloud Meetings, lapotop, HP dan properti yoga 
ibu hamil seperti matras, balok, strep, dan selimut, MMT.

4. Pelaksanaan

Pelaksanaan kegiatan dilakukan melalui daring dengan menggunakan aplikasi Zoom Cloud Meetings dan WhatsApp Grup, mengingat kondisi masih dalam pandemic COVID-19. Dilaksanakan pada tanggal 23 oktober 2020 mulai pukul 09.00 sampai dengan selesai.

5. Evaluasi

Evaluasi dilaksanakan untuk mengetahui efektifikat pelaksanaan pengabdian masyarakat ini yaitu para ibu hamil dengan sadar mulai melakukan pemberdayaan diri, untuk aktif belajar, berlatih dan mempersiapkan proses persalinannya dengan lancar dan minim trauma, mengaplikasi gerakan yoga hamil sederhana dirumah secara mandiri. Evaluasi dilaksanakan pada tanggal 28 Januari 2021 bertempat di Balai Desa Madegondo dengan dihadiri perwakilan ibu hamil, didampingi kader, bidan desa dan perangkat desa.

\section{Hasil dan Pembahasan}

Kegiatan pengabdian masyarakat pemberdayaan diri ibu hamil dengan prenatal gentle yoga mempersiapkan persalinan yang lancar, nyaman dan minim trauma di kelas ibu hamil Desa Madegondo, Kecamatan Grogol, Kabupaten Sukoharjo atas kerja sama Bidan Desa Magendo dan Puskesmas Grogol terlaksana pada tanggal 23 Oktober 2020. Dengan jumlah partisan 29 ibu hamil dan diikuti kader kesehatan. Pelaksanaan menggunakan aplikasi Zoom Cloud Meetings dan juga WhatApp untuk ibu ibu hamil yang mengalami kendala bergabung di Zoom Cloud Meetings.

Ibu hamil sendiri masuk dalam kategori yang rentan terhadap infeksi virus corona. Pada situasi pandemic COVID-19 diharapkan ibu hamil tidak hanya berdiam diri dan tidak melakukan pemberdayaan diri untuk dapat mendapatkan hak nya untuk melalui proses kehamilan yang sehat dan mempersiapan persalinan dengan baik baiknya.

Dalam upaya menurunkan angka kematian ibu (AKI) diiperlukan strategi yang efektif yaitu meningkatkan upaya kesehatan. Upaya edukasi dan latihan dalam persiapan persalinan normal, hingga saat melahirkan ibu hamil juga keluarga siap secara lahir dan batin.
Berbagai program upaya menurunkan angka kematian ibu yang diimplentasikan pemerintah kepada ibu hamil akan optimal ketika ada gerakan perubahan perilaku dari ibu hamil itu sendiri, oleh karena itu perlu adanya pemberdayaan masyarakat yang dilakukan untuk menumbuhkan kesadaran, kemauan, dan kekampuan, serta menjadi penggerak dalam menurunkan angka kematian ibu. Pemberdayaan masyarakat dilakukan dengan membekali pengetahuan dan ketrampilan bukan saja pada ibu hamil melainkan pada suami dan para kader kesehatan (Adriana, 2007)

Kelas ibu hamil bertujuan untuk mengedukasi para calon orang tua agar dapat menjalani proses kehamilan dan persalinan dengan sehat, kelas ibu hamil adalah kelompok belajar bagi para calon ibu tentang kesehatan ibu dan anak. Materi pada kelas ibu hamil di Desa Madegondo disampaikan oleh bidan atau tenaga kesehatan, namun juga bisa bertukar ilmu atau sharing dengan ibu hamil yang menjadi peserta kelas, sehingga kegiatan ini sekaligus dapat menjadi ajang sosialisasi bagi ibu hamil

Dalam pengabdian masyarakat ini kami berinovasi, yang biasanya kelas ibu hamil dilakukan secara langsung, karna COVID -19 beberapa bulan ini kelas ibu hamil tidak dilakukan karena tidak diperkenankan untuk berkumpulkan bersama, maka dari itu kelas online dengan metode Zoom Cloud Meetings dan juga WhatApp dapat menjadi alternative pemecahan masalah.

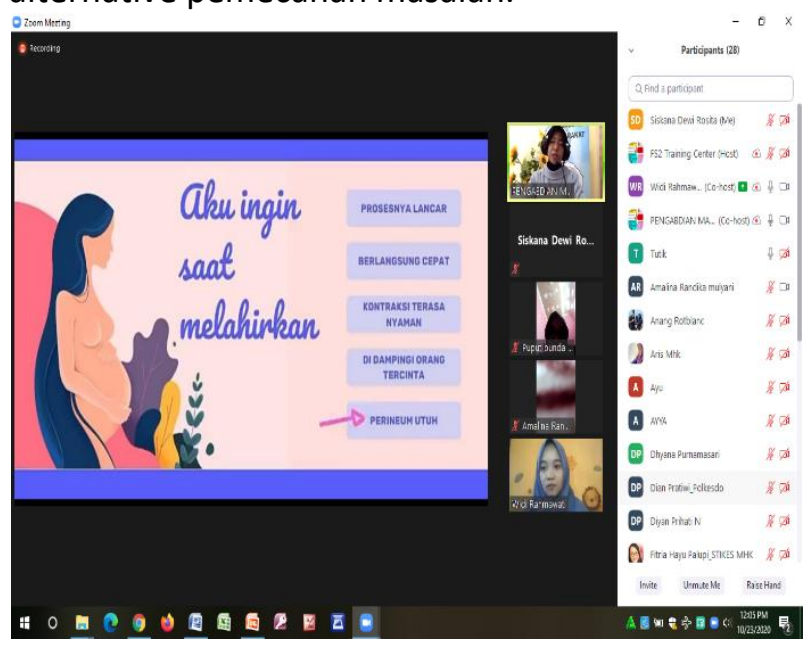

Gambar 1. Pemaparan Materi Prenatal Gentle Yoga

Ibu hamil tetap bisa melakukan pemberdayaan diri, belajar dan mempersiapkan persalinan yang lancar, nyaman dan minim trauma. Dalam pengabdian masyarakat dimulai pukul $09.00 \mathrm{~s} / \mathrm{d}$ 11/00 WIB. Kegiatan dilakukan ditempat masing 
masing karena dapat diikuti hanya dengan menggunakan smartphone atau laptop, mengingat saat pandemic COVID-19 tidak diijinkan untuk melakukan perkumpulan. Diawali dengan registrasi perserta (ibu hamil mengisi link absensi), pembukaan acara, sambutan oleh Bidan Desa Madegondo Ibu Hesti Ramayani, Amd. Keb, Pemaparan materi Oleh Ibu Siskana Dewi Rosita, SST, Kes menjelaskan tentang pengertian Prenatal Gentle Yoga, Manfaat Prenatal Gentle Yoga, Anatomi dan Fisiologi perubahan tubuh ibu hamil, pemutaran vidio Prenatal Gentle Yoga, dan praktik Prenatal Gentle Yoga yang bisa dilakukan ibu hamil menjelang bersalin dan beberapa asanas yang bisa dilakukan di bed persalinan untuk mempercepat proses persalinan oleh Putriyana dan Ibu Siskana Dewi Rosita, SST, M. Kes. Dilanjutkan dengan tanya jawab, diakhiri penutupan dan memberian dooprize pada peserta pengabdian.

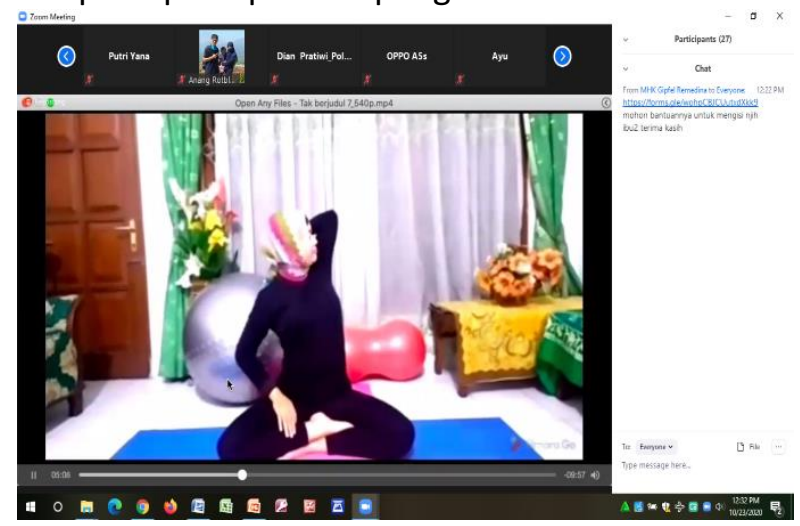

Gambar 2. Penjelasan dengan Vidio Prenatal Gentle Yoga

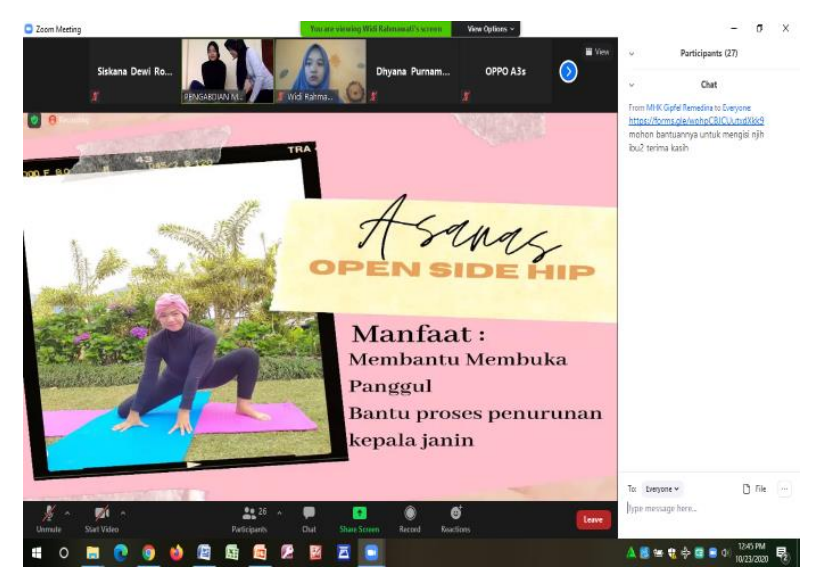

Gambar 3. Penjelasan Asanas Prenatal Gentla Yoga

Pada hari kamis, 28 Januari 2021 terlaksana evaluasi pelaksaan bertempat di gedung balai Desa Madegondo, turut hadir kader kesehatan, perwakilan ibu hamil, perangkat desa dan bidan Desa Madegondo dengan tetap menerapkan protokoler kesehatan. Kegiatan pengabdian masyarakat disambut baik oleh Pimpinan Desa Madegondo, ibu hamil, kader dan bidan desa, dan semoga kegiatan ini dapat memberikan manfaat bagi sesama.

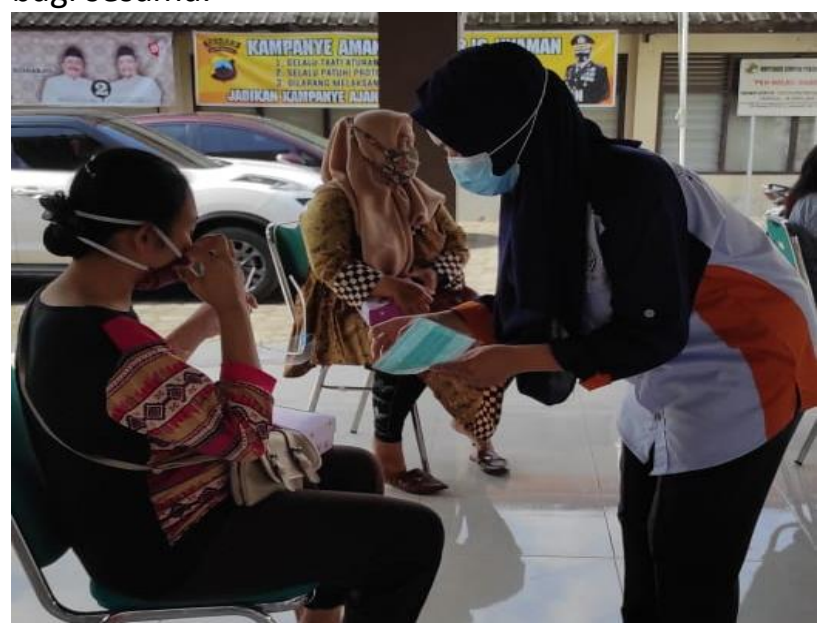

Gambar 4. Evaluasi Pelaksanaan

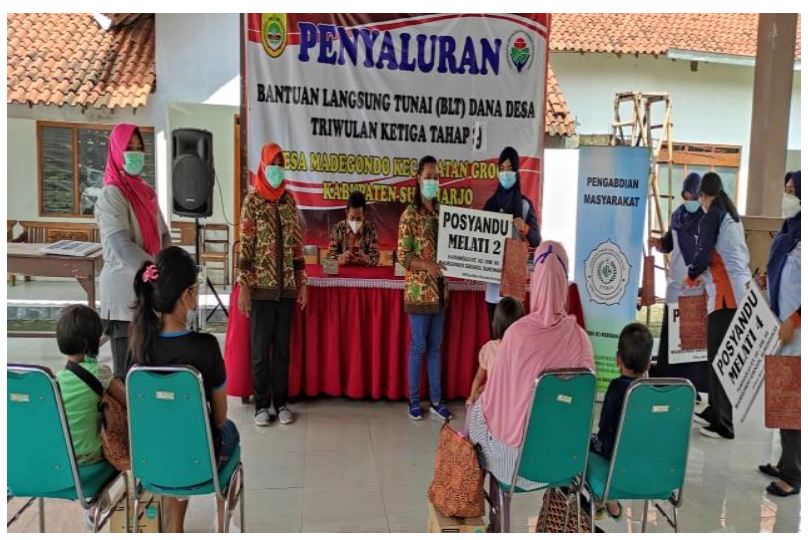

Gambar 5. Pemberian PMT untuk ibu hamil dan kenangkenangan bagi kader

Dalam kegiatan ini kami juga melibatkan para kader kesehatan Desa Madegondo. Mengingat kader kesehatan adalah ujung tombak terdekat dengan masyarakat, harapannya dapat mendampingi ibu hamil, sampai persalinan.

Meski terbukti efektif dan efisien, model pembelajaran kelas ibu hamil Virtual ternyata mempunyai keterbatasan yang harus diantisipasi, terutama menyangkut faktor ketersediaan dan kemudahan akses internet, kontinyuitasnya, motivasi dan disiplin diri, serta mekanisme balikan langsung (feedback) yang lemah dan bahkan tidak ada (Julaeha, 2010) 
Simpulan

Kegiatan pengabdian masyarakat pemberdayaan diri ibu hamil dengan prenatal gentle yoga mempersiapkan persalinan yang lancar, nyaman dan minim trauma di kelas ibu hamil Desa Madegondo, Kecamatan Grogol, Kabupaten Sukoharjo atas kerja sama Bidan Desa Magendo dan Puskesmas Grogol terlaksana pada tanggal 23 Oktober 2020. Dengan jumlah partisan 29 ibu hamil dan diikuti kader kesehatan. Pelaksanaan menggunakan aplikasi Zoom Cloud Meetings dan juga WhatApp untuk ibu ibu hamil yang mengalami kendala bergabung di Zoom Cloud Meetings.

Pada hari kamis, 28 Januari 2021 terlaksana evaluasi pelaksaan bertempat di gedung balai Desa Madegondo, turut hadir kader kesehatan, perwakilan ibu hamil, perangkat desa dan bidan Desa Madegondo dengan tetap menerapkan protokoler kesehatan. Kegiatan pengabdian masyarakat disambut baik oleh Pimpinan Desa Madegondo, ibu hamil, kader dan bidan desa, dan semoga kegiatan ini dapat memberikan manfaat bagi sesama.

Dalam kegiatan ini kami juga melibatkan para kader kesehatan Desa Madegondo. Mengingat kader kesehatan adalah ujung tombak terdekat dengan masyarakat, harapannya dapat mendampingi ibu hamil, sampai persalinan.

\section{Ucapan terima kasih}

Tim Pengabdian masyarakat mengucapkan terima kasih kepada STIKes Mitra Husada Karanganyar dan LPPM STIKes Mitra Husada Karanganyar yang telah mendukung kegiatan ini, Bidan Desa Madegondo, Kepala Desa Madegondo, Puskesmamas Grogol, Sukoharjo, Kader-kader kesehatan Desa Madegondo, yang banyak membantu kegiatan pengabdian masyarakat ini.

\section{Daftar Pustaka}

Aprilia, Y.R.B. 2014. Gentle Birth : Melahirkan Nyaman Tanpa Rasa Sakit. Jakarta : PT Gramedia Widiasarana Indonesia.

Aprilia, Y. 2017. Bebas Takut Hamil dan Melahirkan .Jakarta: PT Gramedia Pustaka Utama.

Didi, M.N. 2014. Nyeri Persalinan. Jakarta: EGC

Julaeha S. Virtual Learning: Pemanfaatan Teknologi Informasi dan Komunikasi untuk Meningkatkan Kualitas Pembelajaran. Vol. 11, Journal of Visual Languages \& Computing. 2010. p. 287-301.

Kasdu, D. 2015. Solusi Problem Persalinan. Jakarta: Puspa Swara.

Nisman, W. 2011. Ternyata Melahirkan itu mudah \& Menyenangkan. Yogyakarta.

Rohani, dkk. 2011. Asuhan kebidanan pada masa persalinan. Jakarta : Salemba Medika 